Acta Crystallographica Section A

Foundations of Crystallography

ISSN 0108-7673

\section{Gjønnes Medal in Electron Crystallography - call for nominations}

The Gjønnes Medal in Electron Crystallography recognizes an outstanding contribution to the field of electron crystallography. The Gjønnes Medal is accompanied by a certificate and funding to present an invited Keynote Lecture at the triennial International Congress of Crystallography.

Administration. This award is managed by the Awards Subcommittee of the Commission on Electron Crystallography (CEC) of the IUCr. This Sub-committee is responsible for soliciting and evaluating and recommending a nominee to members of the CEC for final approval, or recommending that no award be made.

Rules and eligibility. Nomination for the Gjønnes Medal is open to scientists and engineers in all areas of electron crystallography defined in the broadest context as the branch of science that uses electron scattering and imaging to study the structure of matter. Nominees of any nationality are eligible. It is expected that the nomination will be for a single person. However, since breakthrough innovations often involve more than one individual, the nomination can be for two or three people, maximum. In the case of multiple nominees, it must be shown that each person contributed roughly equally to the innovation.

The Award will not be bestowed in absentia except in extraordinary circumstances. Current members of the CEC, members of the IUCr Executive Committee and previous recipients of the Gjønnes Medal are not eligible.

Previous recipients of the Gjønnes Medal are

2008: J. Gjønnes

2011: A. Howie and M. Whelan

Nomination procedure. The next Gjønnes Medal will be awarded at the Montreal Congress in August 2014.

The nomination packet should be sent to the Chair of the CEC, Professor L. M. Peng (lmpeng@pku.edu.cn), and should include:

(i) A letter of not more than 3000 characters evaluating the nominee's qualifications in the field of electron crystallography and identifying the specific work to be recognized. There is no nomination form, so this letter is considered the nomination 'application'.

(ii) Curriculum vitae of the nominee.

(iii) A list of the most important publications of the nominee.

(iv) At least two, but no more than four, seconding letters.

The deadline for receipt of nominations is 30 April 2013.

\section{M. Peng}

Chair of the Commission on Electron Crystallography 